\title{
Un Quevedo políticamente desconcertante. Antiimperialismo, antibelicismo, antiesclavitud, antidiscriminación contra negros y mujeres, y una visión utópica, en La Fortuna con seso y la hora de todos
}

\author{
Henry Ettinghausen \\ University of Southampton \\ Padró, 7 \\ 17120 La Pera (Girona) \\ España \\ ettinghausen@telefonica.net \\ [La Perinola, (Issn: 1138-6363), 21, 2017, pp. 99-130] \\ DOI: $10.15581 / 017.21 .99-130$
}

La Fortuna con seso y la hora de todos es una de las obras más extraordinariamente imaginativas de la literatura española: un invento conceptual y lingüístico que podría considerarse como el colmo de la genialidad de su brillante creador. Se trata de una pieza que lleva lo caricaturesco y lo grotesco hasta niveles pocas veces conseguidos. Al mismo tiempo, la crítica más perspicaz ha reconocido en Fortuna una obra compleja y nada fácil de abarcar ${ }^{1}$.

Una de las peculiaridades de Fortuna consiste en que el cuerpo de la obra se estructure en dos partes bien diferentes, aunque no diferenciadas explícitamente por su autor. La primera parte sigue las pautas marcadas por sus primeros escritos burlescos y satíricos, tipificados en sus pragmáticas y memoriales cómicos y corrosivos y en los Sueños y el Buscón. La segunda parte entronca con los numerosos análisis críticos que hizo del panorama político de su tiempo, tanto en lo que se refiere a España, como a Europa en general, y casi hasta al mundo entero, en obras escritas en las décadas de 1620 y 1630, tales como Grandes anales de quince días, Mundo caduco y desvarios de la edad, Lince de Italia o la Carta a Luis XIII. De manera que Fortuna, escrita sin duda principalmente hacia mediados de la década de 1630, representa una doble, y

1. Para muestra, un botón. En su edición bilingüe, Bourg, Dupont y Geneste (Quevedo, L'heure de tous, 1980, p. 7) comienzan su «Avant-propos» con la frase siguiente: «Testament ou chef-d'oeuvre de Quevedo, difficile dans sa forme ou énigmatique par son contenu, La hora de todos attire et déconcerte». Como se verá a continuación, ellos no son los únicos lectores de Fortuna que tilden la obra de desconcertante. 
casi última, palabra -satírica y política-, dentro del corpus quevediano. Sin hablar de su carga moral ${ }^{2}$.

De los cuarenta «cuadros» o escenas -Quevedo no les otorga ningún tipo de nomenclatura-, que se nos presentan en Fortuna, los primeros veintidós versan sobre colectivos entre los cuales se incluyen aquéllos que más frecuente y duramente había castigado en obras satíricas anteriores: médicos, alguaciles, escribanos, boticarios, mujeres afeitadas, hombres que se tiñen el pelo, poetas cultos, dueñas, lisonjeros, embusteros, arbitristas, alcahuetas, letrados, abogados, taberneros, pretendientes... Se trata de figuras que representan tipos, o grupos sociales o profesionales, que viven del engaño, de la hipocresía, de la explotación, de la injusticia o de la ostentación, o bien que sencillamente son mujeres que se maquillan u hombres afeminados y/o cornudos ${ }^{3}$. Mientras que esa primera parte de la obra se estructura mediante unos «cuadros» dibujados en su mayoría con gran concisión, la segunda se explaya casi toda en la escenificación de amplios discursos $-y$, en algunos casos, debates-, sobre cuestiones de práctica y teoría políticas ${ }^{4}$. Las enormes diferencias entre las dos partes incluyen el hecho de que el último de los cuarenta «cuadros» sea más de cien veces más largo que el primero.

En la primera parte de Fortuna, al final de la mayoría de los «cuadros», cuando a las figuras satirizadas les coge «la Hora» y (en principio) se revela «la verdad» y se les dispensa lo que merecen, los tramposos e hipócritas quedan desenmascarados y puestos en ridículo. Sin embargo, en alguna que otra ocasión se produce una solución seria y encomiable a un problema concreto, como, por ejemplo, en el «cuadro» 19, donde los pleiteantes deciden abandonar toda la corrompida máquina de la justicia que les ha dejado arruinados y resuelven buscar «la concordia» por su propia cuenta - «Todos corriendo nos vamos a concertar con nuestros contrarios» (p. 656) $)^{5}$, de manera que el pervertido sistema

2. En cuanto a la fecha de composición de Fortuna, con algunos matices los editores más recientes de la obra siguen la opinión de Fernández-Guerra, quien la fechó en 1635 , con el «cuadro» 39 («La Isla de los Monopantos») escrito en 1639 y añadido alrededor de 1643 (Quevedo, La hora de todos, 1946, p. 381, n. (a)). Bourg, Dupont y Geneste (Quevedo, L'heure de tous, 1980, p. 161, n. 2) dicen que la obra estaba acabada en 1635; López Grigera (Quevedo, La hora de todos, 1975, pp. 11-16) propone un plazo de composición de entre 1628 y 1635, con posibles añadiduras posteriores; y Schwartz (La hora de todos, 2009, p. 29) sugiere que fue escrita hacia mediados de la década de 1630.

3. Recuérdese que, en El mundo por de dentro, Desengaño había explicado que la calle mayor del mundo se llama Hipocresía y que «ninguno es lo que parece» (véase Quevedo, Sueños y discursos, pp. 362, 363).

4. Juárez (1995, p. 506) menciona «la estructura esencialmente dialéctica del texto a nivel formal y conceptual). (Aprovecho para dejar constancia de mi agradecimiento a Encarnación Juárez, William H. Clamurro, James Iffland, Lía Schwartz y Carlos Vaíllo, por haberme facilitado copias de algunos de los artículos que cito). Para un análisis de los discursos de Fortuna, ver Nider (2010).

5. Cito de la edición de Fortuna de Schwartz (2003). Cuando cito varios pasajes seguidos de una misma página, pongo el número de página únicamente la primera vez. 
judicial queda reemplazado por lo que hoy en día se entendería por una especie de autoservicio de mediación, arbitraje y conciliación.

Pasando a la segunda parte de la obra, que es la que nos va a ocupar aquí, mientras que tres de los primeros entre los dieciocho “cuadros» que la componen incluyen también tipos o figuras de la misma índole que la primera -rufianes y médicos («cuadro» 25), fulleros y tramposos (“cuadro» 27), alquimistas y carboneros (“cuadro» 30)-, quedan quince, la gran mayoría de los cuales tratan explícitamente cuestiones tocantes a los principales jugadores en el tablero de la política internacional europea: España, Italia, Holanda, Francia, Alemania, Turquía e Inglaterra, sin hablar de la supuesta conspiración internacional de parte de los judíos para hacerse con el dominio del mundo. Aquí, en plena Guerra de los Treinta Años, a la vez que se desvela la doblez y la voracidad de las grandes y pequeñas potencias, las luchas y rivalidades que las desgarran y su inquina hacia España, se trata, además, de cuestiones y temas generales de la política, como son los tributos, los privados, las monarquías, las repúblicas, los tiranos y las gratificaciones que deberían cobrar ministros y jueces: temas, algunos de los cuales ya se habían tocado, por ejemplo, en Política de Dios o en Marco Bruto.

En la segunda parte se airean, además, cuestiones políticas, sociales y morales que tienen que ver, en especial, con tres colectivos humanos considerados tradicionalmente como 'inferiores', como son los indígenas americanos, los negros y las mujeres, mientras que el último de los cuarenta “cuadros» contiene la visión utópica de un mundo ideal. De manera que Fortuna pasa dramáticamente de la sátira destellante de tipos sociales a la crítica de los intríngulis trazados por los gobernantes europeos, denunciados en especial por su enemistad hacia España, y acaba abordando cuestiones más bien éticas de los derechos humanos.

En las innovadoras introducciones a sus ediciones de Fortuna, Jean Bourg, Pierre Dupont y Pierre Geneste ahondaban en dos aspectos de la obra que apenas si se habían estudiado antes: su relación con la obra filosófica y moral de Quevedo y el subyacente antiolivarismo que impregna muchos de los «cuadros» políticos que predominan en la segunda parte ${ }^{6}$. En lo que sigue, daré por sentado el antiolivarismo de la obra (aunque creo que gran parte de la misma puede leerse legítimamente sin la necesidad de acudir a dicha clave), y no repetiré la lectura neoestoica de la obra, aunque sí insistiré en la idea de que Fortuna concluye con un mensaje indudablemente estoicista. A diferencia del notorio antijudaísmo del «cuadro» 39, conocido como «La Isla de los

6. Me refiero a su edición bilingüe (Quevedo, L’heure de tous, 1980) y a su edición española (Quevedo, La Hora de todos, 1987). Kent (1977) ya había comenzado a leer Fortuna en clave antiolivarista; y luego Riandière la Roche (1979a, p. 59) ya había advocado por la necesidad de interpretar la obra desde «le contexte historique de la lutte de l'aristocratie espagnole contre les représentants du capitalisme marchand», y había entendido el discurso final de Júpiter como incorporando «la dénonciation de l'argent corrupteur, cause du caractère irrémédiable de la méchanceté humaine» (p. 60). 
Monopantos», la presentación, hacia el final de la obra, de los indios de América («cuadro» 36), de los negros («cuadro» 37), de las mujeres y de una visión utópica del mundo (ambas en el «cuadro» 40), es -por lo menos a primera vista, y quizás hasta a segunda-, por decirlo en términos modernos, sorprendentemente progresista ${ }^{7}$. Es, además, algo que en su conjunto se ha comentado poco y, algunas veces, mal. Los tres colectivos humanos (indios, negros y mujeres) figuran entre los grupos de la humanidad que menos se han valorado y que más han padecido prejuicios hasta nuestros días. Su tratamiento en Fortuna, como también la introducción de una inusitada visión utópica, llama la atención, sobre todo cuando se tiene en cuenta la noción tan extendida de que las opiniones y actitudes de su autor hubiesen sido férreamente reaccionarias ${ }^{8}$.

\section{Antimmperialismo}

Uno de los colectivos que en varios «cuadros» de Fortuna se presentan de manera totalmente negativa es la nación holandesa. Además de herejes, los protestantes holandeses se dibujan como empeñados en llevar su larguísima guerra contra España hasta hacerse con las riquezas que se producen en las dos Indias. Así, en el «cuadro» 28, se les califica de

fugitivos a Dios en la fe y a su rey [o sea, al de España] en el vasallaje, amasando su discordia en un comercio público, después de haberse, con el robo, constituido en libertad y soberanía delincuente y crecido en territorio por la traición bien armada y atenta y adquirido, con prósperos sucesos, opinión belicosa y caudal opulento [...] se determinaron, escondiéndole en naves y poblándole de cosarios, a pellizcar y roer por diferentes partes el occidente y el oriente (pp. 693-695)

y se afirma que «han establecido trajino en la India de Portugal, introduciendo en el Japón su comercio», igualmente que en Lima, Potosí, el río de la Plata y Buenos Aires (pp. 696-698).

Quevedo hace que su narrador ponga el énfasis en el desafío a España que representa ese robo, el cual deriva de «la envidia que todos los reyes de Europa tienen a la suprema grandeza de la Monarquía de España» (p. 696). Tanto es así que, en el «cuadro» 28, la actuación de

7. Incluyo el «cuadro» 39 en relación con el antijudaísmo generalizado del corpus quevediano (véase Ettinghausen, 2006). Es muy posible que ese episodio de Fortuna se hubiese escrito en un primer momento como pieza autónoma, ya que se menciona por su propio título en una lista de los papeles incautados cuando Quevedo fue encarcelado en León en 1639 (véase Quevedo, La hora de todos, 2009, p. 18).

8. Rey (2010) detalla, explica y cuestiona esta noción tan extendida. Para una defensa de la tesis de que la obra de Quevedo es tradicionalista, véase Baum (1970). Caminero (1984, p. 98) veía el conservadurismo y el antisemitismo de Quevedo como cprincipios globalmente estructuradores de su pensamiento social a través de toda su obra».

9. Refiriéndose a un pasaje de España defendida dedicado a las conquistas españolas y portuguesas en ambas Indias, Roncero López (Quevedo, España defendida, p. 20) observa que «la obra quevediana $[\ldots]$ es fundamentalmente "eurocéntrica"». 
los holandeses en América se condena tanto porque afecta a los indígenas, como porque es un robo a España: «Van por oro y plata a nuestras flotas como nuestras flotas van por él a las Indias. Tienen por ahorro y atajo tomarlo de quien lo trae y no sacarlo de quien lo crías (p. 695). A la vez que denuncian el corso hecho por los holandeses contra las flotas españolas, estas palabras contienen también una desaprobación implícita de la actuación de los españoles. Además, sacar el oro y la plata «de quien lo cría» recuerda la observación estoicista reiterada numerosas veces por Quevedo según la cual la naturaleza enterró sabiamente bajo montañas lo que los hombres consideran como riquezas ${ }^{10}$.

Los holandeses reaparecen en el «cuadro» 36. Allí se nos presenta el careo en un puerto de Chile entre el capitán de un navío holandés e indios autóctonos del país. La condena de la presencia de los holandeses es, en términos generales, parecida a la del «cuadro» 28 , siendo una de las diferencias significativas entre ambos episodios el que en el primero sea el narrador del «cuadro» quien censura la depredación ejercida por los holandeses en territorios conquistados por los españoles y un anciano holandés quien manifiesta los estragos desastrosos que produce en todas partes, mientras que en el «cuadro» 36 sea un capitán holandés quien defiende la política de su nación, y quien la condena sea un indígena chileno. Aquí, en su censura de los holandeses, el indio no argumenta tanto los efectos infaustos de la riqueza, sino que censura explícitamente el afán imperialista, tanto de holandeses como de españoles, algo que puede extrañar, viniendo como viene de la pluma de un autor que goza de una reputación tan absolutamente patriotera como Quevedo ${ }^{11}$.

Haciéndose eco del «cuadro» 28, el narrador comienza el «cuadro» 36 denunciando a los holandeses por «su sedición y robos» (p. 749). Sin embargo, aquí llama la atención la manera de presentar a «Los indios de Chile, que asistían a la guarda de aquel puerto» como «gente que en aquel mundo vencido guarda belicosamente su libertad para su condenación en su idolatría» (p. 749), un comentario que combina la condena del defecto que padecen los indios de no dejarse convertir al cristianismo con admiración por la virtud que muestran defendiendo su

10. Por ejemplo, en una obra temprana, la silva «A una mina» (Quevedo, Poesía original completa, núm. 136). También en una obra tardía, Providencia de Dios, p. 246: «¿Quién negará que estos tesoros en el nombre, que se levantan con el corazón de los que en ellos ponen su felicidad, no son el oprobrio y desprecio de la tierra, a quienes, como sabidora de su contagio, escondió con tanto cuidado la naturaleza, que los cargó los montes encima, borrando sus caminos con los golfos y apartándolos de nuestra codicia con el divorcio de todo el Océano?». Juárez (1995, pp. 510-512), ofrece un excelente análisis del «cuadro» 28 en el cual también comenta la crítica implícita al imperialismo español. Además del «cuadro» 28, Juárez comenta los «cuadros» 35 y 38.

11. Clamurro (2004, esp. pp. 99-105) comenta los «cuadros» 28 y 36 de una manera que se anticipa a nuestro análisis. Riandière la Roche (1979b) comenta los «cuadros» 24 y 33. 
libertad ${ }^{12}$. Pero lo que más nos debería llamar la atención es el hecho de que, según cuenta el narrador, los indios «embistieron con armas a la gente de la nave, entendiendo eran españoles, cuyo imperio les es sitio y a cuyo dominio perseveran excepción» (p. 749). En efecto, impresiona el hecho de que Quevedo haga que los indios embistan a los holandeses porque piensan que son españoles - una referencia, sin duda, a la resistencia armada protagonizada por los mapuches en la Guerra de Arauco-, y que, visualizando la situación desde el punto de vista de los pueblos sojuzgados, su narrador califique de «sitio» el imperio que España pretende ejercer sobre ellos ${ }^{13}$.

La respuesta del capitán del navío a esta recepción, que dista tanto de ser acogedora, consiste en procurar tranquilizar a los indios, asegurándoles que los que acaban de llegar en la nave no son españoles, siendo sus primeras palabras precisamente: «Soy capitán holandés» (p. 750). Sin embargo, los indios no se fían de él, puesto que le identifican como europeo, sino que se prestan a escucharle «con las armas en las manos», ya que, según explica el narrador, «Es nación tan atenta a lo posible y tan sospechosa de lo aparente que reciben las embajadas con el propio aparato que a los ejércitos». A los indios, ya se ve, se los presenta al lector, no como salvajes ignorantes o fáciles de embaucar, sino como gente prudente que desconfía de forasteros con aspecto de europeos, a los que reconocen como depredadores sencillamente por el tratamiento que ya han recibido a manos de los españoles.

El discurso del capitán es una pequeña obra maestra de retórica colonialista. Ofreciendo a los indios «amistad y comercio», se jacta de las ganancias conseguidas por los holandeses en perjuicio de España -«la mitad de sus estados» (p. 751), incluyendo Pernambuco y Paraíba-, y del comercio que le han arrebatado: «el tesoro del palo, tabaco y azúcar» ${ }^{14}$. Mientras tanto, impávidos ante los ofrecimientos que les hace el capitán, los indios siguen presentándose como gente perspicaz y comedida cuando insisten en que, antes de poder dar una respuesta al trato que se les está ofreciendo, tendrán que consultar con su Consejo. Por su parte, el holandés se revela como incapaz de apreciar esas virtudes, pues practica el rancio truco atribuido a todo pretendiente a colonizador de pueblos 'primitivos', o sea procurar ablandarlos con chucherías. En palabras del

12. En España defendida (p. 172) Quevedo ya había insistido en la importancia de las armas españolas, entre otras cosas, porque, si no hubiese sido por ellas, "gozaran en las Indias seguros los ídolos su adoración». Riandière la Roche (1991) comenta las controversias coetáneas sobre la licitud de la conquista de América en relación con el «cuadro» 36 de Fortuna.

13. Sin embargo, en España defendida, comenzado en 1609, Quevedo había loado la presencia española en ultramar: «Quién sino Dios, cuya mano es miedo sobre todas las cosas, amparó a Cortés para que lograse dichosos atrevimientos, cuyo premio fue todo un Nuevo Mundo?» (España defendida, p. 175).

14. En el «cuadro» 28 ya se había aseverado que los holandeses «se han apoderado de la mejor parte del Brasil, donde no sólo tienen el mando y el palo, como dicen, sino el tabaco y el azúcar» (p. 696). 
narrador: «conociendo la naturaleza de los indios, inclinada a juguetes y curiosidades, por engaitarlos la voluntad, les presentó barriles de butiro, quesos, frasqueras de vino, espadas y sombreros y espejos y, últimamente, un tubo óptico que llaman antojo de larga vista» (p. 753).

Cuando les coge la Hora, el jefe chileno rechaza la oferta del capitán, justificándose por haberse rebelado los holandeses contra el rey de España, desconfiando de ellos por haberle robado el Brasil y recelando de la intención de sus ofrecimientos. Además, el indio se distancia de la codicia de los holandeses, ya que, «conservándonos en la patria que nos dio la naturaleza, defendemos lo que es nuestro; conservamos la libertad, no la hurtamos» (p. 755). Aunque el indio está discutiendo aquí con un holandés, parece evidente que estos argumentos valdrían igualmente respecto de la conquista española. Además, el portavoz de los indios lo dice bien claro: «Si a quien nos quitó las Indias se las quitáis, icuánta mayor razón será guardarnos de vosotros que de él!’. Quitarles las Indias a los indios es, por supuesto, lo que habían hecho los españoles.

Aparte de estos razonamientos contra la depredación cometida por los europeos, que éstos sean holandeses o españoles, antes de repudiar al capitán holandés el indio desarrolla un argumento que se repite varias veces, tanto en este episodio de Fortuna, como en otros, o sea el de las nefastas consecuencias que tiene la codicia de las riquezas: «Los cristianos dicen que el cielo castigó a las Indias porque adoraban a los ídolos y los indios decimos que el cielo ha de castigar a los cristianos, porque adoran a las Indias. Pensáis que lleváis oro y plata, y lleváis envidia de buen color y miseria preciosa». Se trata de una actitud claramente estoicista que encontramos en numerosas obras quevedianas y que se anticipa al mensaje estoicista del final de la obra.

El indio sigue demostrando decencia y cordura cuando rechaza las bagatelas que le ofrece el holandés. En particular, no se vende por el telescopio, cuyas virtudes tanto ensalza el capitán, pues lo califica de «instrumento revoltoso» (p. 754), ya que se trata de una herramienta claramente imperialista: «Traer a sí lo que está lejos es sospechoso para los que estamos lejos; con él debisteis de vernos en esta grande distancia». Y recalca su lección, asegurando que, «con éste [instrumento] que trae a los ojos lo que está lejos, no miraremos jamás a vuestra tierra ni a España» (p. 756). Una vez más, lo que se denuncia no es tan sólo la codicia mercantil de los holandeses, sino cualquier interferencia por parte de naciones explotadoras, empezando explícitamente por la española.

El que estas ideas coincidan con actitudes estoicistas se desprende, por ejemplo, de las siguientes frases, escritas por Justo Lipsio -el venerable humanista flamenco, editor de la obra filosófica de Séneca e historiador de la filosofía de los estoicos-, en una carta enviada en 1603 a Bartolomé Leonardo de Argensola: 
Vencido por vosotros, os ha vencido, a su vez, el Nuevo Mundo y ha agotado o debilitado vuestro antiguo vigor. Nunca han llevado otro fruto las riquezas. Considera toda época, y me darás la razón. Nosotros mismos los belgas, ¿qué padecemos desde hace tiempo sino el castigo del lujo, que hemos heredado como un vicio ${ }^{15}$ ?

Dos años más tarde, Lipsio expresaría la misma opinión al propio Quevedo, adaptando un verso de Horacio para sentenciar: «Conquistadas las Indias, han conquistado también ellas a su fiero vencedor ${ }^{16}$. En España defendida, comenzada en 1609, esa noción de una nación venida a menos resucitaba en el encomio pronunciado por el mismo Quevedo de «las costumbres de los buenos hombres de Castilla, de quinientos y de cuatrocientos años a esta parte», de «las costumbres propias y primeras de España», a las que calificaba de "modestas, moderadas y según justa ley y diciplina», y su denuncia de la decadencia nacional en la actualidad, en la que España se ve «viuda en parte del antiguo vigor» ${ }^{17}$.

Se trata de la nostalgia de una mitificada edad dorada en la que la España cristiana comenzó a liberarse del invasor musulmán, gracias a un austero heroísmo basado en valores éticos: una edad anterior a las conquistas de ultramar destinadas a traer riquezas que -tal como afirma Quevedo en España defendida y demuestra en sus sátiras-, han corrompido la nación, transformando en degeneración socio-moral la varonil empresa castellana de la Reconquista ${ }^{18}$. En Fortuna su visión del glorioso pasado heroico de España sigue en vigor, ostentada, por ejemplo, en el «cuadro» 35, donde el Gran Señor de los turcos alaba la «incomparable valentía» demostrada por los españoles en una época todavía más remota que la Reconquista:

Ellos admiraron el mundo con Viriato y Sertorio; dieron esclarecidas victorias a Aníbal; y a César, que en todo el orbe de la tierra había peleado por la honra, obligaron a pelear por la vida. Pasaron de lo posible los encarecimientos del valor y de la fortaleza en Numancia (pp. 744-745).

15. La cita proviene de la traducción de la carta del latín al castellano hecha por Ramírez (1966, p. 374).

16. Ramírez, 1966, p. 414. En el «cuadro» 28, un viejo asevera: «Los glotones de provincias siempre han muerto de ahíto» (p. 699); y, hablando de los romanos: «En tanto que fueron pobres, conquistaron a los ricos, los cuales haciéndolos ricos y quedando pobres, con las mismas costumbres de la pobreza pegándoles las del oro y las de los deleites, los destruyeron y, con las riquezas que les dieron, tomaron de ellos venganza». En Providencia de Dios (p. 298) Quevedo traduce y elogia una de las fuentes clásicas de esta noción, un pasaje de la Sátira vi de Juvenal: «Ahora padecemos largamente los males de la paz, más cruel que las armas: se apoderaron de Roma las delicias y dan venganza de ella al mundo que ella venció. Ningún crimen ni maldad de la concupiscencia falta desde que pereció la pobreza romana».

17. Quevedo, España defendida, pp. 175, 174, 172, 175.

18. El que España defendida se dedicase a Felipe III indicaría que esa denuncia de la España de su tiempo tuviese, por lo menos en su concepción, una clara finalidad política. 
Se trata del valor, no de lucrarse a costa de naciones ajenas, sino de defender a España contra invasores. Quevedo ya lo había dejado claro en España defendida, donde elogiaba las hazañas de los españoles y portugueses en ambas Indias específicamente «para quitar la paz a los ídolos», no para explotar sus riquezas ${ }^{19}$.

\section{Antibelicismo}

En su discurso, el capitán holandés procura ganar la simpatía de los indios, dando a entender que ambas naciones tienen algo fundamental en común, ya que los holandeses fueron, «pocos años ha, vasallos y patrimonio del grande monarca de las Españas y Nuevo Mundo» (p. 751), mientras que los indios son los únicos que, por su valentía, se ven «fuera del cerco de su corona». Siendo, como él argumenta, el enemigo común España, el capitán inserta una durísima crítica a Felipe II por haber sido ese monarca, en última instancia, el responsable de las terribles matanzas ocurridas en las guerras de Flandes:

Pusímonos en libertad con grandes trabajos, porque el ánimo severo de Felipe II quiso más un castigo sangriento de dos señores [Egmont y Horn] que tantas provincias y señorío. Armonos de valor la venganza y con guerras de sesenta años y más, continuas, hemos sacrificado a estas dos vidas más de dos millones de hombres, siendo sepulcro universal de Europa las campañas y sitios de Flandes (p. 751) ${ }^{20}$.

En vista de los elogios que hace Quevedo en otros lugares de la figura de Felipe II, esta crítica puesta en boca del holandés del «ánimo severo» del monarca puede resultar sorprendentemente dura, por más que el mismo capitán reconozca que los holandeses también eran en parte culpables, ya que lo que les motivó a rebelarse, dice, fue la sed de venganza por la ejecución de los condes de Egmont y de Horn. Sin embargo, parece probable que, además de poner esa crítica en boca del capitán que representa la rebeldía de los holandeses, el mismo autor compartiese hasta cierto punto su opinión, dado que su denuncia del comportamiento de la política de Felipe II en Flandes recuerda, como veremos, los sentimientos expresados en la correspondencia mantenida por el joven Quevedo con el viejo Justo Lipsio, probablemente unos treinta años antes de la composición de Fortuna.

19. España defendida, p. 175.

20. En el «cuadro» 38, Quevedo permite que Carlos I de Inglaterra mencione la Armada Invencible, tildándola claramente de desastre para España: «la armada española, con que el duque de Medina Sidonia, viniendo a invadir estos reinos, dejando en estos mares tan miserables despojos» (pp. 768-769); y, en El chitón de las tarabillas (p. 226) lamenta «la herencia tan necesitada que dejaba [Carlos V] a Felipe II, que, con el Escorial y otras niñerías, la extremó más». En general, no obstante, y sobre todo en comparación con los de Felipe III y IV, Quevedo alaba el reinado de Felipe II (véase Ettinghausen, 1999). 
En la segunda de las cartas conservadas que le envió Lipsio, en octubre de 1604, el eminente estudioso flamenco se había lamentado de la situación que padecían sus compatriotas:

Bien dijo de Troya el antiguo poeta al llamarla común sepulcro de Europa y de Asia. Yo lo diría de Bélgica, pues desde hace casi cuarenta años arrastra y diezma la flor de la milicia de Europa ${ }^{21}$.

A lo que había respondido Quevedo, al mes siguiente:

¿Qué puedo decirte acerca de España sin que me tiemble la voz? Vosotros sois presa de la guerra. Nosotros lo somos del ocio y de la ignorancia. Allí se consumen nuestros soldados y nuestras riquezas. Aquí nos consumimos nosotros ${ }^{22}$.

La visión tan negativa de lo que acabaría siendo la Guerra de los Ochenta Años mantenida entre España y los holandeses protestantes no representa, pues, tan sólo la opinión de un capitán ficticio holandés, sino también, sin duda, la de su creador. Al final de su discurso, el indio también alude a ese tema tan recurrente de la segunda parte de Fortuna, o sea la visión de una Europa consumida por la guerra: «Quitaisnos para tener qué os quiten; por lo que sois nuestros enemigos, sois enemigos unos de otros» (pp. 755-756). En definitiva, se trata del furor de la guerra, denunciado repetidas veces a lo largo de la obra, en la que se lamenta de que naciones protestantes maten a otras católicas y, sobre todo, que naciones católicas se maten entre sí.

El discurso antibelicista del holandés no acaba con su denuncia de las masacres ocasionadas por los españoles en Flandes, sino que incluye también una reprobación de las atrocidades cometidas por los conquistadores contra los nativos americanos, una censura que evidentemente refleja algunos de los argumentos constitutivos de la Leyenda Negra:

Hemos considerado que no sólo han ganado estas infinitas provincias los españoles, sino que en tan pocos años las han vaciado de innumerables poblaciones y pobládolas de gente forastera, sin que de los naturales guarden aun los sepulcros memoria y que sus grandes emperadores, reyes, caciques y señores fueron desaparecidos y borrados en tan alto olvido que casi los esconde con los que nunca fueron (pp. 751-752).

Con el empleo de desaparecer como verbo transitivo aplicado a colectivos humanos, tan lamentablemente corriente en nuestros tiempos, el capitán holandés dramatiza los genocidios cometidos por los españoles. Por otra parte, su alocución hace referencia a la heroica resistencia

21. La cita proviene de la traducción de la carta del latín hecha por Ramírez (1966, pp. 393-394). El «antiguo poeta» que cita Lipsio es Catulo.

22. Ramírez, 1966, pp. 403-404. 
de los indios a ser esclavizados - «en vuestro coraje, se defiende a la esclavitud la generación americana» (p. 752)_- ${ }^{23}$, para apelar, una vez más, a lo que indios y holandeses tienen en común y ofrecerles «para vuestra defensa y pretensiones, navíos y artillería, capitanes y soldados» a cambio de «escala franca en vuestro dominio», un tipo de pacto internacional que sigue estando muy en boga hasta hoy en día.

Desde luego, era totalmente previsible que Quevedo introdujese la crítica de la intervención de los holandeses en los quehaceres imperialistas españoles. Lo que lo era mucho menos es que dejase expresar también, y tan claramente, oposición al proyecto imperial español -o, para ser exactos: que pusiera esa noción tan firmemente en boca de dos de los protagonistas de la obra-, y que hiciese que uno de ellos denunciase también los horrores de la guerra de los Países Bajos. Podríamos conjeturar que lo que quería Quevedo era que España mantuviese su hegemonía en Europa, pero evitando la tremenda sangría que representaba, entre otras, la guerra holandesa, la cual entendió que se prolongaba en gran parte mediante la plata americana.

Sin embargo, en el «cuadro» 36 , a la crítica hecha tanto por el indio al imperialismo europeo como por el holandés a las actuaciones bélicas de parte de España en América y en Flandes, no se le ofrece contestación ni solución alguna. La impresión que da ese “cuadro» podría ser que Quevedo se desespera ante los desastres de la guerra, tanto en el Nuevo Mundo como en el Viejo, a la vez que ve como una causa del declive de los valores nacionales españoles su dependencia de las riquezas importadas desde sus colonias ${ }^{24}$. Una cosa, quizás, serían las proezas bélicas de moderado alcance promovidas por un duque de Osuna en el Mediterráneo para salvaguardar los intereses españoles en Europa; otra, ese anticipo de la carnicería masificada de la Primera Guerra Mundial en Flandes que Lipsio y Quevedo, y muchos más de su propia generación, observaron con espanto y desesperación ${ }^{25}$. El «cuadro» 36 contendría, pues, además de una defensa de los indios masacrados o explotados por los españoles, una condena de las nefastas consecuencias de la adquisición por España de riqueza fácil en América y de los horrores de las guerras tan cruentas que ensangrentaban a Europa.

23. Aquí «se defiende a» tendría el significado de 'se defiende de?.

24. Comentando detalladamente este “cuadro», Roncero López (2010, pp. 27) observa que Quevedo, «en La Hora de todos, y a través del indio chileno, decide asumir el papel del escritor moralista que abomina de la avaricia, de la codicia del oro que ha empujado a muchos de sus compatriotas a cruzar el charco y que mancha y corrompe lo que hubiera sido de otro modo una empresa admirable», concluyendo que «el sometido [o sea, el indio] tiene la última palabra, una palabra de afirmación de su ser y de su libertad, y de desafío ante los holandeses y españoles que pretenden sojuzgarlo» (p. 30).

25. En el «cuadro» 24, una defensa del mando español en Nápoles, Quevedo no deja escapar la oportunidad de loar, una vez más, al duque de Osuna: «incomparable virrey, invencible capitán general» (p. 679). 


\section{ANTIESCLAVITUd Y ANTIDISCRIMINACIÓN CONTRA LOS NEGROS}

¿Será por pura casualidad que el «cuadro» 36, que acabamos de comentar, finalice con el rechazo, por parte del indio, del telescopio que le regalaba el capitán holandés, un instrumento que era capaz, entre otras cosas, de distinguir en el sol «la mancha negra» (p. 756)? Sea como fuese, el «cuadro» siguiente versa sobre los negros. Más exactamente, relata una reunión de negros (no se especifica cuáles ni dónde) «para tratar de su libertad». Bourg, Dupont y Geneste comentan este episodio, tildándolo de “Esta irónica defensa de los negros» ${ }^{26}$. Sin embargo, por más que contenga chistes y bromas, no resulta obvio que esa defensa sea necesariamente irónica.

Es cierto que, dado el tratamiento satírico $-\mathrm{y}$ se espera que, para el lector moderno, ofensivo-, de los negros que hallamos en el conocidísimo romance de Quevedo «Boda de negros», lo que podríamos esperar de la defensa de ese colectivo en Fortuna sería precisamente, como mínimo, que fuese irónica. Sin embargo, en el «cuadro» 37, el narrador comenta, acerca de la (libertad» de los negros, que es «cosa que tantas veces han solicitado con veras» (p. 756). Llaman la atención estas dos últimas palabras. ¿Significan simplemente 'de verdad, realmente', como hoy en día «de veras»? ¿O apuntan a la «eficacia, fervor y actividad con que se ejecuta o desea algo» ${ }^{27}$ ? Sea como fuese, por si concluyésemos precipitadamente que el narrador de este «cuadro» debe tomarse como un testigo totalmente neutro, o hasta favorable, a la pretensión de los negros de lograr su libertad, en su relato no se resiste a la tentación de llamarlos (iaquí sí que en la línea burlesca de «Boda de negros»!) «bayetas», o sea paños negros, sin duda con el significado de «trapos sucios» $)^{28}$.

Sin embargo, el largo discurso en contra de la esclavitud de los negros hecho por “Uno de los más principales» (p. 756) de entre ellos, es elocuente, persuasivo y, al parecer, está casi enteramente desprovisto de ironías. Ese portavoz de los negros comienza su plática con una rotunda afirmación: “Para nuestra esclavitud no hay otra causa sino la color, y la color es accidente y no delito» (p. 757), argumentando que el color es efecto «de la asistencia de la mayor hermosura, que es el sol». Ahora bien, a la vez que el negro rechaza el racismo cuando defiende a su raza, sí que resulta irónico el que él mismo incumba en racismo como base de su propuesta para que otra raza sea esclava, en vez de la negra. Anticipándose al furibundo embate contra los judíos representado por «La Isla de los Monopantos» («cuadro» 39), el negro asevera que quienes tendrían que ser esclavos son los judíos: «fuera más justo que lo fueran en todas partes los naricísimos, que traen las caras con proas

26. Quevedo, La Hora de todos, 1987, p. 313, n. 508.

27. DRAE, sv. «veras».

28. Por cierto, bayetas aparece también en «Boda de negros»: «Por toalla trujo al hombro / las bayetas de un entierro» (Quevedo, Poesía original completa, núm. 698, vv. 77-78). 
y se suenan un peje espada» (pp. 757-758), frase que casi coincide con tres versos del notorio soneto antijudío de nuestro autor «A un hombre de gran nariz»: “ćrase un naricísimo infinito», “Érase el espolón de una galera» y (érase un peje espada mal barbado» ${ }^{29}$. Y, por si su estratagema de pasar la pelota no quedase lo suficientemente clara, el negro añade otra pulla más -(somos contrasayones» (p. 758)-, la cual recuerda otro verso más del mismo soneto: “érase una nariz sayón y escriba» ${ }^{30}$.

Después de este pasaje crudamente antijudío, el portavoz negro vuelve a razonar de forma más plausible y lógica, argumentando que el prejuicio por el color de la piel es sencillamente irracional, ya que, «¿Por qué no consideran los blancos que si uno de nosotros es borrón entre ellos, uno de ellos será mancha entre nosotros?». Sin embargo, vuelve, por segunda vez, a buscar otro colectivo que, en su opinión, sí merecería ser esclavizado, aunque aquí su razonamiento parece que se basa en parte en motivos tirando a burlescos: «Si hicieran esclavos a los mulatos, aun tuvieran disculpa, que es canalla sin rey, hombres crepúsculos, entre anochece y no anochece, la estraza de los blancos, y los borradores de los trigueños y el casi casi de los negros y el tris de la tizne». No obstante, lo que se insinúa aquí es también algo serio: haber sido despreciados muchas veces los mulatos, tanto por negros como por blancos. A la vez, vemos cómo el portavoz negro cede a la tentación que se ofrece a cualquier nación despreciada de cargar la culpa a otra, más despreciada todavía.

El siguiente argumento que utiliza es difícil de calibrar, pues no resulta obvio determinar si el lector debe tomarlo en serio: «De nuestra tinta han florecido en todas edades hombres admirables en armas y letras, virtud y santidad; no necesita su noticia de que yo refiera su catálogo». ¿Existía tal «noticia»? ¿Se podría haber confeccionado un «catálogo» de las virtudes «en armas y letras, virtud y santidad» reconocidas en los negros? ¿O se trata de una absurda fanfarronada de parte del portavoz, o de un sarcasmo de parte de Quevedo? Ninguno de los editores modernos de la obra comenta este pasaje. Sin embargo, lo cierto es que la afirmación por parte del corifeo debería por lo menos dar a pensar.

$\mathrm{Su}$ discurso, que hasta este punto ha sido en general bastante pertinente a la cuestión de si los negros merecen emanciparse, se adentra

29. Quevedo, Poesía original completa, núm. 513. Para ese soneto, véase Molho, 1982.

30. Schwartz (Quevedo, La Fortuna con seso, 2003, p. 758, n. 939-41) apunta la similitud con estos versos del soneto, pero sin comentar las implicaciones que supone el desprecio de los judíos expresado por el negro. Clamurro (1992, p. 843) comenta: «el episodio 37, uno de los más cortos y engañosamente irónicos (el de los negros, posiblemente ubicado en África) parece tratar de la injusticia de la esclavitud de la que los negros son víctimas principales, mientras al mismo tiempo contiene una sutil implicación antisemita». En el «cuadro» 39, el narrador de Fortuna ofrece otra caricatura antisemita centrada en una nariz exageradamente larga: «Rabí Maimón [...] se llegó al oído de Rabí Saadías y, rempujando con la mano estado y medio del pico de la nariz para podérsele llegar a la oreja, le dijo» (p. 783). 
ahora en una consideración que nos puede parecer irrelevante, o por lo menos muy secundaria, pero que se anticipa al colectivo que trataremos a continuación, y viene a ser una de las máximas obsesiones expresadas por Quevedo en sus obras satírico-burlescas. Se trata de las «mujeres afeitadas», a las cuales ya había dedicado el «cuadro» 3 de Fortuna. El argumento que ahora expone el negro consiste precisamente en el hecho de que, a diferencia de las mujeres blancas, las negras no se maquillan. Entre los blancos, «las mujeres, siendo negras o morenas, se blanquean con guisados de albayalde y las que son blancas, sin hartarse de blancura, se nievan de solimán», mientras que «Nuestras mujeres solas, contentas con su tez anochecida, saben ser hermosas a escuras» (pp. 758-759). Estas observaciones se podrían identificar como una justificación estoicista, pues lo que diferencia aquí a mujeres blancas y negras es que las primeras hacen todo lo posible por huir de su estado natural, mientras que las últimas se contentan con su propia condición. Este mensaje se reforzaría cuando el portavoz afirma que «Nosotros no desmentimos las verdades del tiempo, ni con embustes asquerosos somos reprehensión de la pintura de los nueve meses» (p. 759), dando a entender, según parece, que los negros no disimulan sus arrugas cuando se hacen viejos, ni las negras su embarazo cuando están preñadas.

Al pronunciar el portavoz la pregunta retórica «¿Por qué, pues, padecemos desprecios y miserable castigo? s, les coge la Hora, y toma la palabra un negro viejo, el cual propone dos cosas. La primera nos lleva otra vez a la proposición de que quiénes realmente merecen ser esclavos no son los negros, sino los judíos. Si el portavoz se había referido a los judíos mediante referencias caricaturescas a sus supuestamente exageradas narices, ahora el viejo se anticipa a la temática de «La Isla de los Monopantos», pero refiriéndose a los judíos mediante su referencia al supuesto cabello rojo de Judas y de los judíos en general:

que si la color es causa de esclavitud, que se acuerden [todos los reinos de Europa] de los bermejos, a intercesión de Judas, y se olviden de los negros, a intercesión de uno de los tres reyes ${ }^{31}$.

Tanto es así, que el viejo aboga por la destrucción, no tan sólo de sus «arrabales» (o sea, las juderías, o guetos), sino de ellos mismos: «los bermejos, con todos sus arrabales, se consuman», haciéndose eco de Execración contra los judíos, el panfleto más furibundamente antijudío de

31. A propósito de bermejo, Covarrubias dice: «son tenidos los bermejos por cautelosos y astutos", pero desde antiguo se ha hablado de Judas como pelirrojo y se ha asociado a Judas, el traidor, con los judíos, y el haber cobrado él dinero por su traición como algo típicamente judío». El soneto de Quevedo «A Judas Iscariotes, ladrón no de poco» contiene el verso «Bien está lo bermejo a lo ahorcado» (Quevedo, Poesía original completa, núm. 540, v. 5). Para la conseja del judío rojo, véase Gow, 1994. 
Quevedo, escrito en 1633, o sea en la misma época que se supone que compuso gran parte de Fortuna ${ }^{32}$.

Lo segundo que propone el viejo negro es que los blancos «tomen casta de nosotros», es decir que se mezclen blancos con negros, una proposición que se basa en una consideración político-moral -la mortífera actuación de los blancos protestantes en el norte de Europa-, una evidencia más del descorazonamiento compartido, desde el primer decenio del siglo, por Lipsio y Quevedo: «el ampo [=blancura] de los flamencos y alemanes tiene revuelto y perdido el mundo, coloradas con sangre las campañas y hirviendo en traiciones y herejías tantas naciones» (pp. 759-760). De manera que el viejo negro reafirma la denuncia, hecha por el indio en el «cuadro» anterior, de la terrible sangría que representaba la Guerra de los Treinta Años, y más específicamente la de los Ochenta, con la diferencia de que aquí se da la culpa a los enemigos protestantes de España, mientras que antes se había inculpado nada menos que a Felipe $\mathrm{II}^{33}$.

Resumiendo, pues: lejos de rechazar la pretensión de los negros a que dejen de ser esclavos, y sin que llegue a abordar realmente las posibles justificaciones a favor o en contra de la esclavitud, lo que hace aquí Quevedo, a través de los dos protagonistas negros, es proponer otros colectivos que, a su ver, se la merecerían más ${ }^{34}$. Se trata de dos bestias negras suyas, representadas como más negras todavía que los propios negros: los judíos y los protestantes ${ }^{35}$.

\section{ANTIDISCRIMINACión CONTRA LAS MUJERES}

Antes de la conclusión de la obra, que se sitúa -al igual que su comienzo-, en un Olimpo fantasmagórico, Fortuna termina con un «cuadro» que es mucho más largo que cualquiera de los demás. De hecho, no es realmente un «cuadro», sino cuatro, siendo la razón por la que se presenta en ediciones modernas como uno solo el hecho de que la Hora no coja por separado a cada uno de los cuatro objetivos que trata, sino que aparece solamente al final. El «cuadro» 40 trata, en efecto, de

32. En Execración contra los judios Quevedo llega a decirle a Felipe IV: «Quemar y justiciar los judíos solamente será castigo [...] en todas las puertas de Vuestros reinos han de hallar muerte y cuchillo [...]. Perezcan, Señor, todos, y todas sus haciendas [...] borrando esta mala generación de Vuestros reinos y asolándolos» (Quevedo, Execración, pp. 113, 118, 129).

33. En su espléndido ensayo sobre la ideología expresada en Fortuna-que no citan en sus respectivas ediciones ni Bourg, Dupont y Geneste, ni López Grigera, ni Schwartz, y que yo leí cuando este artículo estaba casi terminado-, Iffland (1981, p. 60) comenta, acerca de este episodio: «Una perspectiva más radical sobre los problemas de la Europa Occidental sería difícil de imaginar». Dicho artículo se había publicado antes en inglés (Iffland, 1980).

34. Riandière de la Roche (1981) examina el «cuadro» 37 en relación con los debates acerca de la esclavitud en la época.

35. El «cuadro» 34 de Fortuna está dedicado a «Los alemanes, herejes y protestantes, en quienes son tantas las herejías como los hombres» (p. 728). 
los respectivos méritos de monarquías y repúblicas, de los derechos de la mujer, de la privanza de Richelieu, y de un sistema de gobierno ideal. El que este final represente la culminación de las disquisiciones políticas anteriores se entiende cuando se avisa al lector desde la primera frase que, para oír estos razonamientos, asisten «Los pueblos y súbditos a señores, príncipes, repúblicas, reyes y monarcas» para «tratar de sus conveniencias y a remediar y descansar sus quejas y malicias y desahogar su sentir, opreso en el temor de la soberanía» (pp. 785-786). Es un auditorio que parece representar, como mínimo, a todos los habitantes de Europa, pues «Había gente de todas naciones, estados y calidades» (p. 786), pero que «estaba mezclado en tumulto fiero y en discordia furiosa», desde luego la discordia representada en casi toda la segunda parte de la obra y que alude, entre otras cosas, a las tensiones internacionales y a las guerras que asolaban el continente.

En el primer episodio del «cuadro», la polémica sobre monarquías y repúblicas se expone en forma de una disputa entre un saboyano crítico con su gobierno ducal y un genovés contrario a su gobierno republicano. En el tercero, «un francés monsiur» (p. 794), que «se carcomía de rabia», denuncia «el miserable estado en que se halla Francia, mi patria y la opresión de los franceses so el poder de Armando, cardenal de Richeleu». No es demasiado extraño que un republicano quiera ser gobernado por un monarca, ni que el súbdito de una monarquía prefiera vivir en una república. Tampoco que un francés se queje de la privanza de Richelieu. Pero, entre ambos episodios, viene la extraordinaria defensa de la mujer.

En la larga introducción a su edición española de Fortuna, Bourg, Dupont y Geneste conceden tan sólo tres frases a este episodio, con un comentario al cual no se puede menos que calificar de equivocado. Dicen:

Aparentemente, la discusión sobre la condición femenina nos aparta luego del debate propiamente político. De hecho, basándose en la ideología antifeminista de los juristas y teólogos, Quevedo pretende demostrar que la mujer, ser inferior y diabólico, tentador y corruptor, pervierte el funcionamiento de las leyes. Siendo un peligro para el Estado, debe ser apartada del poder ${ }^{36}$.

En su perspicaz análisis del mismo episodio, Aurora Czeglédi observa, acerca de este comentario de los editores franceses: «Esta interpretación parece el resultado de una lectura superficial ${ }^{37}$.

En primer lugar, la discusión sobre la condición femenina, que se interpone entre el debate sobre monarquías y repúblicas y la crítica del estado miserable de Francia, no nos aparta en absoluto del debate propiamente político, ya que tiene sus antecedentes en las problemáti-

36. Quevedo, La Hora de todos, p. 90.

37. Czeglédi, 2010, p. 70. 
cas políticas que ya hemos tratado: los derechos de los indios y de los negros. Junto con éstos, la cuestión del estatus político, jurídico y social de la mujer constituye el tercero de estos tres aspectos de lo que hoy en día se entiende por los derechos humanos. Pero, lo que es más, en la espléndida defensa que hace aquí la portavoz de los derechos de la mujer, no parece en absoluto que se pretenda demostrar seriamente que las mujeres sean un peligro para el Estado, ni se menciona para nada que sean inferiores o diabólicas. Todo lo contrario: lo que se argumenta es precisamente su condición, como mínimo, de igualdad con los hombres.

Por su parte, Lía Schwartz, en su edición de Fortuna publicada en Clásicos Castalia, parece que no reconoce en absoluto el alcance de este episodio, limitándose a referirse en su introducción a «un escuadrón de mujeres que exige una reforma de la educación en su beneficio» ${ }^{38}$. Sin embargo, acerca de la defensa de la mujer que ahora comentaremos, Luisa López Grigera sí que se había dado plena cuenta de lo extraordinaria que parece esa defensa en Fortuna, viniendo como viene de la pluma de Quevedo:

Esta tesis, la de la supresión de los privados en Francia, y sobre todo el tremendo alegado feminista puesto en boca de una mujer bella, a pesar de las dificultades con que un letrado al que «le chorreaban las barbas» intenta disuadirla de sus peticiones de justicia y equiparación en la república, nos muestran a un Quevedo que parece haber girado acaso más de ciento ochenta $\operatorname{grados}^{39}$.

En efecto, López Grigera opina que se trata de argumentos que «increíbles pueden parecer en boca del escritor prototipo de la misoginia» ${ }^{40}$. Sin embargo, ella deja la cosa aquí, sin intentar comentar ni analizar la naturaleza de esa incredibilidad. Lo que sí hace, y es algo que al parecer contradice las palabras que acabamos de citar, es con posterioridad poner en su edición de Fortuna la nota siguiente al comienzo de este episodio: “Las mujeres, "feministas", también hacen un papel grotesco desde la presentación ${ }^{41}$. Pero, el papel que juegan las mujeres en este episodio de Fortuna, ¿es realmente grotesco?

38. Quevedo, La Hora de todos, 2009, p. 36. En un artículo sobre voces femeninas en la sátira del siglo XVII, Schwartz (1994, p. 385) sí que se había referido al discurso en defensa de la mujer que estamos comentando, afirmando que «se articula en citas de los discursos reivindicatorios de la mujer que circularon en el XvII», y comentando que «su recepción depende del juego que entabla con las acusaciones vertidas por el jurista que los rechaza».

39. López Grigera, 1971, p. 19.

40. López Grigera, 1971, p. 20.

41. Quevedo, La Hora de todos, 1975, p. 207, n. 679. En su excelente estudio, Fernández Mosquera (1997, p. 161) afirma que «En La hora de todos es abrumadora la presencia de sátiras antifemeninas», sin indicar si incluye en esta aseveración el episodio que comentamos aquí. 
El episodio comienza con la aparición de «una manada de catedráticos» (p. 790), a los que persigue «un escuadrón de mujeres [...] a chillidos», y prosigue con el discurso de una de ellas, «cuya hermosura era tan opulenta que se aumentaba con la disconformidad de la iram, una noción que se halla bien distanciada del concepto clásico de la belleza femenina como algo estático y pasivo. Es de notar la primera palabra que pronuncia esta amazona: «Tiranos», pues se dirige directamente a los gobernantes (por supuesto, masculinos) que, casi por definición, sojuzgan a las mujeres en todo el orbe. Así comienza un discurso extraordinario, enérgico y elocuente, que merece que se le examine con un poco de detalle.

Al inicio de su alocución, haciendo notar que ella habla en nombre de la mitad del género humano, la portavoz pregunta directamente a los tiranos: «¿por cuál razón [...] habéis hecho vosotros solos las leyes contra ellas sin su consentimiento y a vuestro albedrío?». A continuación detalla, con contundencia, en un pasaje brillante, algunas de las afrentas que representa dicha discriminación: haber privado a las mujeres de la educación, "por envidia de que os excederemos», y de las armas, "por temor de que seréis vencimiento de nuestro enojo los que lo sois de nuestra risa»; haberse los hombres «constituido en árbitros de la paz y de la guerra», de manera que las mujeres "padecemos vuestros delirios»; ejercer una doble moral en cuestiones de género, pues «El adulterio en nosotras es delito de muerte y en vosotros entretenimiento de la vida. Quereisnos buenas para ser malos, honestas para ser distraídos» (pp. 790-791); y oprimir los hombres en cada momento la vida de las mujeres:

No hay sentido nuestro que por vosotros no está encarcelado; tenéis con grillos nuestros pasos, con llave nuestros ojos. Si miramos, decís que somos desenvueltas; si somos miradas, peligrosas $y$, al fin, con achaque de honestidad, nos condenáis a privación de potencias y sentidos (p. 791).

La oradora denuncia la desconfianza para con las mujeres de parte de los hombres, la cual hace que «Más son las que hacéis malas que las que lo son», y termina exigiendo por lo menos algún tipo de remedio a la discriminación:

Hoy es día en que se ha de enmendar esto o con darnos parte en los estudios y puestos de gobierno, o con oírnos y desagraviarnos de las leyes establecidas, instituyendo algunas en nuestro favor y derogando otras que nos son perjudiciales (pp. 791-792).

No cabe la menor duda: este discurso habría sido atrevido en cualquier país del mundo hasta bien entrado el siglo XIX, de manera que asombra el que se escribiese doscientos años antes $\mathrm{y}$, sobre todo, el que hubiese salido de la pluma de un escritor que, tal como comenta 
Luisa López Grigera, es considerado generalmente como prototipo de la misoginia.

Desde luego, esta aparente contradicción pide a voces que se le busque una explicación. Acerca de este discurso indiscutiblemente feminista, Bourg, Dupont y Geneste comentan que conviene «tener en cuenta la refutación pronunciada por el catedrático» ${ }^{42}$. En efecto, a diferencia de los episodios dedicados a los indios y los negros, en los que no se ofrece respuesta alguna a las reivindicaciones de ambos colectivos, aquí sale un doctor - sin duda, uno de entre la «manada de catedráticos» a los que perseguían, airadas, las mujeres al comienzo del episodio-, que procura refutar sus pretensiones. Sin embargo, cabe observar cómo se le presenta a él y a los argumentos que emplea en su peroración.

Se trata de «Un doctor, a quien la barba le chorreaba hasta los tobillos» (p. 792) -iésta sí que es una descripción más bien grotesca!-, el cual, dice el narrador, «fiado en su elocuencia, intentó satisfacerlas» con sus razones, de lo que se puede inferir que sus razonamientos fallaron, pese a la elocuencia en que él se fiaba. Efectivamente, sus razones son pobres, falaces y ofensivas, pues empiezan rebosando de sexismo. Lo primero que hace es tratar a las mujeres como objetos: «Con grande temor me opongo a vosotras, viendo que la razón frecuentemente es vencida de la hermosura, que la retórica y dialéctica son rudas contra vuestra belleza», una confesión, más bien, de su propia debilidad, prejuicios y ofuscación. Pero luego echa mano de un argumento tan literalmente tradicionalista que nos lleva a Génesis, un argumento (por lo menos, claramente, para la portavoz de las mujeres) totalmente ilógico y fuera de lugar:

«¿̇qué ley se os podrá fiar, si la primera mujer estrenó su ser quebrantando la de Dios? ¿Qué armas se pondrán como disculpa en vuestra mano, si con una manzana descalabrasteis toda la generación de Adán?»\$3.

Luego, ante la denuncia de la indefensión de la mujer ante la ley, el doctor se explaya en contraponer el poder que afirma tienen las mujeres para corromper a los jueces, de manera que «Si los jueces gobiernan el mundo, y las mujeres a los jueces, las mujeres gobiernan y desgobiernan el mundo y desgobiernan a los que le gobiernan». Luego les brinda un argumento que podría haber salido en cualquiera de las obras satíricas de nuestro autor: «Si tenemos los cargos y los puestos, vosotras os gastáis en galas y trajes» (p. 793), o sea que los hombres

42. Quevedo, La Hora de todos, 1987, p. 351, n. 612. En la misma nota, Bourg, Dupont y Geneste leen así la intención del autor en el comienzo del discurso de la mujer portavoz: «El apóstrofe inicial ("tiranos") recuerda de modo irónico que el eje esencial del debate es político. En este plano Quevedo es absolutamente hostil a toda concesión, aunque no cierre la puerta a toda discusión sobre otros aspectos de la condición femenina», pero no explican cómo llegan a intuir tan categóricamente la intención del autor.

43. Candelas Colodrón (2005, pp. 33-34) comenta la presencia de la «condición maléfica» de Eva en la obra de Quevedo. 
son seres responsables y que trabajan para la sociedad, mientras que las mujeres son inútiles y no hacen sino malgastar ${ }^{44}$. El paternalismo del doctor culmina en la frase: «Quejaros de que os guardamos es quejaros de que os estimemos; nadie guarda lo que desprecia», acabando su patética refutación de la posición feminista aseverando: «Según lo que he discurrido, de todo sois señoras, todo está sujeto a vosotras».

Naturalmente, la reacción de las mujeres no se hace esperar: «todas juntas se dispararon contra el triste doctor en remolino de pellizcos y repelones». Es cierto que no se dice explícitamente quién tiene razón, las mujeres o el doctor, pero tampoco hace falta. No creo que represente una lectura anacrónica apreciar que los argumentos de las mujeres se presentan como potentes y manifiestamente racionales y razonables, mientras que los del «triste doctor» suenan a flacos, irrelevantes e inefectivos ${ }^{45}$.

\section{UNA VISIÓN UTÓPICA}

El último de los cuatro episodios del «cuadro» final de Fortuna consiste en el larguísimo discurso hecho por un letrado, un discurso que enlaza con el temario de la primera parte de este mismo «cuadro», o sea los respectivos méritos de monarquías y repúblicas, como también con la tercera, es decir la disputa entre «un francés monsiur y un italiano monseñor» (p. 794). Ahora es cuestión de «la propuesta que, en nombre de todos» (p. 796) hace ese letrado ante (aquellas multitudes», a las cuales se define como un (auditorio pacífico», añadiendo el narrador, sin embargo, que «a todos los había revuelto y persuadido a pretensiones tan diferentes y desaforadas».

Vale la pena insistir en los extraordinarios términos utópicos con los que el letrado comienza su propuesta, abogando por la libertad, la paz, la justicia, la dignidad, la igualdad, el buen gobierno, y el entendimiento entre plebeyos y nobles:

La pretensión que todos tenemos es la libertad de todos, procurando que nuestra sujeción sea a lo justo y no a lo violento; que nos mande la razón, no el albedrío; que seamos de quien nos hereda, no de quien nos arrebata; que seamos cuidado de los príncipes, no mercancía y en las repúblicas, compañeros y no esclavos; miembros y no trastos; cuerpos y no sombra. Que el rico no estorbe al pobre que pueda ser rico, ni el pobre enriquezca con

44. Hay que reconocer, sin embargo, que el despilfarro que representarían las mujeres constituye una queja frecuente en Quevedo; por ejemplo en España defendida: «su hermosura es tan costosa y de tanto daño a España, que sus galas nos han puesto necesidad de naciones extranjeras para comprar, a precio de oro y plata, galas y bujerías, a quien sola su locura y devaneo pone preciom (España defendida, p. 176).

45. Juárez (1995, p. 516) comenta, con toda la razón: «El tono grave, junto a la clara articulación y dignidad de las exigencias femeninas, a través de un portavoz no ridiculizado como es el de una mujer bella e inteligente, ofrece gran peso a sus reivindicaciones. Hacer corresponder la intención de Quevedo a un esquema aceptado a priori e inmovible sobre su machismo, esquema que identifica la voz del autor con la del portavoz masculino, el juez barbado, destruye en gran parte la validez de la escena e imposibilita lecturas nuevas». 
el robo del poderoso. Que el noble no desprecie al plebeyo, ni el plebeyo aborrezca al noble y que todo el gobierno se ocupe en animar que todos los pobres sean ricos y honrados los virtuosos y en estorbar que suceda lo contrario (pp. 796-797) ${ }^{46}$.

Haciéndose eco del debate mantenido al comienzo de este «cuadro» sobre monarquías y repúblicas, el letrado sigue abogando claramente por la paz, el entendimiento y la armonía: «Las repúblicas han de tener con los reyes la unión que tiene la tierra, en quien ellas se representan, con el mar, que los representa a ellos». No obstante, llama la atención una opinión pesimista del orador, según la cual «Deben hacer la guerra a los unos reyes con los otros», la cual justifica por la noción de que los reyes «son como el hierro y la lima que, siendo no sólo parientes sino una misma cosa y un propio metal, siempre la lima está cortando y adelgazando el hierro», o sea que las guerras entre monarquías serían endémicas, y hasta inevitables.

Refiriéndose a las repúblicas, el letrado defiende «la mercancía», o sea el comercio - pero, evidentemente, un comercio justo que no implica conquista ni explotación-, porque «enriquece y lleva los hombres por el mundo ocupados en estudio práctico, que los hace doctos de experiencias» (p. 798), a la vez que apoya la utilidad de «los estudios políticos y matemáticos». El letrado propone, además, que «Los juegos públicos se ordenarán del ejercicio de las armas [...] porque sean juntamente de utilidad y entretenimiento», y opina que «entonces será decente frecuentar los teatros cuando fueren academias), es decir (según parece dar a entender) cuando ofrezcan entretenimiento decoroso, a la vez que pedagógico. Luego el orador combina austeridad, caridad y estoicismo cuando asegura que

Hase de condenar por infame la ostentación en trajes y sólo ha de ser diferencia entre el pobre y el rico que éste dé el socorro, y aquél lo reciba y entre noble y plebeyo, la virtud y el valor.

Habiéndose dedicado a cuestiones que, dice, tocan a las repúblicas, el prolijo letrado pasa a hablar “de los súbditos de los reyes», y aquí prosigue la dura crítica de los privados que había desgranado el «francés monsiur» en el episodio anterior de este «cuadro», arremetiéndose ahora el letrado duramente contra los franceses que creen que «los príncipes que para mejor gobernar sus reinos se entregan totalmente a validos». Luego pasa al tema de «las quejas contra los tiranos» (p. 799), dictaminando sin ambages que «El tirano, por miseria y avaricia, es fiera; por soberbia, es demonio; por deleites y lujuria, todas las fieras y todos los demonios» (p. 800). Tal como recalcan Bourg, Dupont y Geneste, sus diatribas contra privados y tiranos pueden, y seguramen-

46. Iffland (1981, p. 65) comenta acertadamente: «es difícil no percibir la cualidad subversiva que "se aparece" en el pasaje». 
te deben, leerse en especial como críticas implícitas de la privanza de Olivares, sobre todo cuando añade: “Yo no sé de quién hablo ni de quién no hablo; quien me entendiere me declare» (p. 799).

Finalmente, el letrado responde al deseo de defenderse los súbditos "contra el arbitrio de los que nos gobiernan, mediata o inmediatamente» (p. 801), tanto en las repúblicas como en las monarquías. Sus remedios consisten en que «los consejeros sean perpetuos en los consejos, sin poder tener ni pretender ascenso a otros», con el fin, de esta forma, de evitar que ambicionen otros puestos. También se opone a los premios, o sea las gratificaciones, pues en Roma se pagaba «con un ramo de laurel o robre más heridas que daba hojas, victorias de ciudades, provincias y reinos» (p. 802), a la vez que propone que «Para consejeros de guerra y estado sólo sean suficientes y admitidos los valientes y experimentados» $y$, para las judicaturas, «los doctos y los desinteresados».

El letrado termina su gran discurso dirigiéndose a su auditorio con las siguientes palabras: «Yo he dicho. Vosotros diréis lo que se os ofrece, y propondréis los remedios más convenientes y practicables» (p. 803). Y es aquí, al final del último «cuadro» de la obra, donde -justo después de ofrecer la receta para un mundo mejor, o hasta ideal-, el narrador nos deja de repente, no con una refutación del programa expuesto, como en el episodio dedicado a las mujeres, sino con la imagen sumamente deprimente de una humanidad que se demuestra incapaz de seguir esa serie de sabios o, mejor dicho, utópicos consejos:

como era multitud diferente en naciones y lenguas, se armó un zurrido de jerigonzas tan confuso que parecía haberse apeado allí la tabaola de la torre de Nembrot: ni los entendían ni se entendían. Ardíase en sedición y discordia el sitio y en los visajes y acciones parecía junta de locos o endemoniados.

Cuando la coge la Hora, parece que no cambia nada, pues la multitud sigue igual de enfurecida -«se mezclaban en pendencia»-, y al final, el lector se queda con una imagen que representa toda la antítesis de una utopía:

La discordia del campo de Agramante en su comparación era un convento de vírgenes vestales y, para sosegarlos, se vieron todos en peligro de perderse. En fin, detenidos, y no acallados, se fueron todos quejosos de lo que cada uno pasaba y rabiando cada uno por trocar su estado con el otro (p. 805).

A diferencia de las defensas de los indios y de los negros, aquí, donde la narración presenta un enorme auditorio reunido para escuchar reformas radicales que remedien los males tanto de monarquías como de repúblicas, el resultado es un caos de quejas y de cólera. Pero ¿̇la multitud descarta las pretensiones del letrado como ilusorias, como imposibles o como indeseables? ¿Y qué debemos hacer nosotros? Como 
muy bien dijo James Iffland en su brillante artículo pionero sobre la ideología en Fortuna, «Lo que nos queda es un intento frustrado de cambio político, pero que ha abierto una caja de Pandora» ${ }^{47}$.

Dentro de dicha caja se encuentra, entre otras cosas, el hecho de que al legista tan utópico se le describa como «un letrado bermejo» (p. 796). En vista de lo que ya hemos dicho acerca de las connotaciones negativas de los pelirrojos, no podemos menos que preguntarnos si ese letrado es realmente de fiar, o si Quevedo está haciendo aquí un guiño al lector para no tomarle del todo en serio. William H. Clamurro observa que

the seemingly logical and benign suggestions of the letrado bermejo [...] are meant to be rejected, to be taken as scandalous and subversive by Quevedo's ideal reader, partly due to the anti-authoritarian implications of some of the man's ideas but even more, due to the symbolic content of the man's identity ${ }^{48}$.

Sin embargo, aunque al letrado locutor, tildándole de «bermejo», se le retrate posiblemente como sospechoso, ello no quita que sus sugerencias, con las insinuaciones tan claramente antiautoritarias que contienen, se expresen con claridad y estén allí presentes en la obra. Que el lector ideal que tenga en mientes Quevedo se escandalice, o no, esas sugerencias utópicas se le han expuesto vigorosamente, y de una manera lógica y benigna. Todo lo cual nos debería llevar, sin duda, a la conclusión de que Fortuna termina con un final abierto y sibilino, y que es una de las obras de nuestro autor que más nos deberían obligar a pensar ${ }^{49}$.

47. Iffland, 1981, p. 72. A lo largo de su artículo, Iffland argumenta que «las contradicciones y rupturas de la obra, aquello que la "descentra", son los productos del impacto desordenador de la ideología» (1981, p. 31). Sorprendentemente, Bourg, Dupont y Geneste (1987, p. 35) comentan, acerca de la acogida infeliz del discurso del letrado: "la discordia y la guerra son pruebas beneficiosas a las que el hombre no debe intentar sustraerse en busca de una paz engañosa».

48. Clamurro, 2004, p. 105. Clamurro (1992, p. 842) observa, sin duda con razón, que la obra refleja, entre otras cosas, «la presión de la actualidad histórica del imperialismo español en decadencia» y «la situación de enajenamiento personal y político de Quevedo durante la última década de su vida». Clamurro (2004, p. 107) opina también que «the whole of the text, and especially the pointedly political, international episodes are pervasively penetrated with an autobiographical undertone of urgency, bitterness, and alienation".

49. Iffland (1981, p. 79) observa, con sagacidad, que la obra «nos deja preguntándonos cuál es, en el fondo, la posición de Quevedo». Juárez, 1995, p. 509, que no comenta ninguno de los episodios que hemos tocado, aserta, sin embargo, y con razón: “Tras una lectura detenida de La hora de todos, se hace obvio que la obra va más allá de un consciente diseño original, de una "ambigüedad calculada", por la multitud de elementos que eluden una explicación única [...] por último, dejando al lector la decisión de juzgar». Por su parte, Bourg, Dupont y Geneste (1987, p. 14) hablaban de «la unidad profunda de la obra». 


\section{Conclusión}

Cuesta, en efecto, determinar lo que pretende Quevedo que se concluya del dramático final del «cuadro» 40, pues lo cierto es que allí no se propone explícitamente ninguna solución. Sin embargo, al parecer, el mensaje que se desprende, por lo menos de toda la parte final de la obra, es que la humanidad no está capacitada para aceptar programas políticos utópicos, incluyendo, sin duda, el fin del imperialismo, de las guerras, de la esclavitud y de la discriminación contra negros y mujeres. $\mathrm{Y}$ eso, sin duda, es lo que determinan los dioses - ese (vulgo de diosecillos» (p. 588), que dice Fortuna al principio de la obra-, en la chocarrera visión olímpica que le da fin.

Al comienzo de la obra, Júpiter se había quejado ante Fortuna de que ella, con sus locuras, disparates y maldades, hiciese dudar a los mortales de que existiesen los dioses y la providencia: «Quéjanse que das a los delitos lo que se debe a los méritos y los premios de la virtud al pecado» (p. 588). A lo que había contestado Fortuna que ella es cuerda y que la culpa la tienen los mortales, ya que algunos virtuosos desprecian los premios que ella les ofrece, otros no se aprovechan de ellos, y otros cogen los que ella no les tiene destinados ${ }^{50}$. Ocasión, la «criada» de Fortuna, como la llama ella, había recitado una genial retahíla de frases hechas que pronuncian los mortales para expresar su remordimiento al no aprovechar las oportunidades que ella les ofrece: «¿Quién dijera?; no pensaba; no miré en ello; no sabía; bien está; qué importa; qué va ni viene; mañana se hará; tiempo hay» (p. 591), etc. Aceptando los argumentos de Fortuna y de Ocasión, Júpiter había decretado que «en un día y en una propia hora, se hallen de repente todos los hombres con lo que cada uno merece» (p. 594). A lo que Fortuna, con una lógica que no se explica, «mezcló en nunca vista confusión todas las cosas del mundo». Y eso es precisamente lo que ocurre al final de la obra, en que les sobreviene a los humanos una confusión en la que «ni los entendían ni se entendían» (p. 803).

Los cuarenta «cuadros» que componen Fortuna se presentan, pues, en principio, para demostrar lo que pasa cuando a los mortales se les da lo que merecen, lo cual, en muchos casos, se traduce en ostentar la verdad, revelándose ellos tales como son, quedando desprovistos de todo lo que hacía que apareciesen como ellos querían. Por ejemplo, en el «cuadro»1, al médico se le despacha en una sola frase, pues -cuando le coge la Hora que ha de darle lo que merece-, se revela como un verdugo. Sin embargo, como ya hemos visto, ese esquema no se mantiene a lo largo de toda la obra, ya que, después de cogerles la Hora, los discursos de autodefensa de los indios y de los negros quedan sin resolución o

50. Las quejas de parte de Fortuna se parecen bastante a las que hace Desengaño en El mundo por de dentro: “en el mundo todos decís que queréis desengaño y en teniéndole, unos os desesperáis, otros maldecís a quien os le dio y los más corteses no le creéis» (Quevedo, Sueños y discursos, p. 361). 
respuesta alguna, mientras que la réplica que ofrece el triste doctor barbudo a las mujeres es vacua, insultante e inmerecida. Lo que también es cierto, como acabamos de constatar, es que el discurso utópico del letrado que da fin al largo «cuadro»40, en vez de llevar a la humanidad a un mundo mejor, la hunde en desorden y locura. Cuando la Hora coge al concurso expectante, no cambia nada, sino que incrementa todavía más la rabia que ya llevaba dentro. Es de suponer que ese final tan desesperadamente infeliz constituye implícitamente la respuesta a todos, o la mayoría de, los colectivos que aparecen en la segunda parte de la obra, incluyendo a los indios, los negros y las mujeres. Sin embargo, es un final que resulta altamente problemático, pues deja en el aire una pregunta obvia: ¿por qué razón el caos que se revela al final del «cuadro» 40 corresponde a lo que merece la humanidad?

En cuanto a la opinión que dictaminan los dioses al final de Fortuna, Júpiter deduce que, cuando la Hora le ha dado a cada uno lo que merecía, «los que eran hombres de bien, se hayan hecho pícaros y los que eran pícaros, hombres de bien [...] el que hace mal cuando puede, le deja de hacer cuando no puede» (p. 805) ${ }^{51}$. Pero, ¿eso es realmente lo que se ha demostrado? En la primera parte de la obra, en la gran mayoría de los casos, lo que pasa cuando les coge la Hora es que los pícaros quedan retratados como tales. Y, en cuanto a los episodios de la segunda parte que hemos comentado, cuando a los indios y los negros les coge la Hora, no pasa nada en absoluto; $\mathrm{y}$, cuando coge a las mujeres, lo único que pasa es que se les ofrece un risible discurso pronunciado por un absurdo doctor.

También resulta sorprendente lo que Júpiter dictamina al final de todo: «La Fortuna encamine su rueda y su bola por las rodadas antiguas y ocasione méritos en los cuerdos y castigos en los desatinados, a que asistirá nuestra providencia infalible y nuestra presencia soberana»-al parecer, una receta definitiva para un mundo justo-, pero, según habían explicado al comienzo de la obra tanto Fortuna como Ocasión, el sistema que habían aplicado en sus rodadas antiguas no funcionaba, porque los humanos sencillamente no aprovechaban lo que se les ofrecía ${ }^{52}$.

Para procurar resolver toda esta trifulca -o quizás, más bien, para esquivar toda responsabilidad-, Júpiter concluye con un veredicto definitivo, el cual reduce toda la problemática tratada por los dioses a una sola y sencilla solución estoicista, la cual se puede resumir de la

51. Hasta cierto punto, este efecto paradójico recuerda, por ejemplo, el dictamen que hace Lucifer, hablando con sus demonios, al final del Discurso de todos los diablos: «Mando que todos vosotros tengáis a la Prosperidad por Diabla Máxima, Superior y Superlativa, pues todos vosotros juntos no traéis la tercera parte de gentes al infierno que ella sola trae. Ésta es la que olvida a los hombres de Dios y de sí y de sus prójimos; ésta los confía de las riquezas, los enlaza con la vanidad, los ciega con el gozo, los carga con los tesoros, los entierra con los oficios» (Quevedo, Discurso de todos los diablos, p. 558).

52. Varios críticos han comentado esta contradicción; entre ellos, Iffland (1981, p. 30): «el efecto de la Hora vengadora, que había de darle a cada persona su merecido, se neutraliza cuando a la Fortuna se le permite volver a "sus rodadas antiguas"». 
siguiente manera: da igual lo que Fortuna y Ocasión reparten a la humanidad; en sí las cosas que dan no son ni buenas ni malas, sino que son indifferentia, y lo único que importa es la manera de aprovecharlas los humanos o de enfrentarse con ellas:

Todos reciban lo que los repartiere [Fortuna], que sus favores o desdenes por sí no son malos, pues sufriendo éstos y despreciando aquéllos, son tan útiles los unos como los otros. Y aquél que recibe y hace culpa para sí lo que para sí toma, se queje de sí propio y no de la Fortuna, que lo da con indiferencia y sin malicia (pp. 805-806) (53 $^{53}$

Bourg, Dupont y Geneste demostraron detalladamente lo mucho que Fortuna tiene en común con obras claramente neoestoicas de Quevedo, en especial con Virtud militante y Providencia de Dios ${ }^{54}$, y Lía Schwartz afirma que, en sus sátiras menipeas, "Quevedo asume la voz de un humanista neoestoico dedicado a educar a sus lectores mediante la crítica de las necedades o maldades de los hombres» ${ }^{55}$. A la vista de lo cual, ella afirma que «este encuentro de La hora no se resuelve con la justa retribución a los transgresores sino que concluiría con una burla de cualquier intento de reforma del mundo ${ }^{56}$. Dicho en otras palabras, lo que tendría en mientes nuestro autor parece ser que el mundo únicamente se podría reformar si la humanidad fuese capaz de adoptar una moral estoicista. Desde luego, el que esa posibilidad sea realista, o no, es otra cuestión, dado que la visión que ofrece Quevedo de la mayor parte

53. En Providencia de Dios, escrito en la prisión en San Marcos de León, Quevedo aseveraría: «puestos, dignidades, honras y riquezas, desprecio, abatimiento, persecuciones y pobreza, son de sí cosas indiferentes, buenas o malas por la virtud o la iniquidad de los que usan de unas y otras. [...] Hay buenos que gozan y tienen felicidad temporal, y buenos que padecen desemparo y desprecio; y sucede lo mismo en los impíos, con que se prueba que no son las riquezas ni la mendiguez por sí males, ni premio o castigo destinado a unos u a otros. [...] los tesoros, las felicidades, las honras, los grandes puestos, la pobreza, la calamidad, el abatimiento, son venenos en unos y remedios y antídotos en otros» (Quevedo, Providencia de Dios, pp. 247, 248, 250). Iffland ve en el final de la obra, además de una solución estoica, (inmovilismo político» (1981, p. 76).

54. Quevedo, La Hora de todos, 1987, esp. pp. 27-54.

55. Quevedo, La Hora de todos, 2009, p. 23. Schwartz argumenta que la obra funciona mediante el estilo cínico de la sátira clásica, en especial de Luciano, ofreciendo "una crítica moralizante de la sociedad en tono cómico» (p. 19) y que Quevedo "había leído cuidadosamente el Sueño de Lipsio» (p. 21). Asevera, además, que el primero de los Sueños se compuso «en imitación del Somnium. Lusus in nostri aevi críticos de Justo Lipsio» (p. 26). Es precisamente en la época en que se suele fechar la composición de la mayor parte de Fortuna, a mediados de la década de 1630, cuando Quevedo publica varias obras neoestoicas: Doctrina estoica, La cuna y la sepultura, De los remedios de cualquier fortuna, Epicteto y Focílides... (véase Ettinghausen, 2009).

56. Quevedo, La Hora de todos, 2009, p. 35. Bourg, Dupont y Geneste observan, oportunamente, que en la segunda parte de la obra «la intervención de la Hora parece obedecer a una lógica más compleja e incluso a veces enigmática» (Quevedo, La Hora de todos, 1987 , p. 46) 
de la humanidad es, para reciclar el título de otra obra política suya, la de habitantes desvariados de un mundo caduco ${ }^{57}$.

Al final del «cuadro» 39, cuando les coge la Hora, los judíos y los monopantos deciden «fundar la nueva secta del dinerismo, mudando el nombre de ateístas en dineranos» (p. 785). Es de suponer que el dinerismo (que nosotros conocemos de sobras) representa exactamente lo contrario del estoicismo, ya que casi lo único que ofrece el dinero es que la gente se dedique a valorar indifferentia. En el capítulo 5 de España defendida el recuerdo de un idealizado pasado glorioso, caracterizado por una mítica y estoica austeridad, quedaba desplazado por la visión de «los tiempos de ahora», en los que la riqueza (emblemáticamente, el oro del Nuevo Mundo) ha destrozado las costumbres antiguas:

Alcanzan a todas partes las fuerzas del dinero [...] pobres, conquistamos riquezas ajenas; ricos, las mismas riquezas nos conquistan. ¿A qué vicio no ha abierto la puerta con llave de oro la avaricia? ${ }^{58}$.

Escrito después de los primeros Sueños y probablemente después de una primera redacción del Buscón, España defendida puede leerse como un análisis paralelo a esas obras en las que tan despiadadamente se caricaturiza la sociedad española, a ojos de Quevedo moralmente perdida, de comienzos del siglo xviı. Un cuarto de siglo más tarde, esas ideas seguirían plenamente vigentes en Fortuna.

Sin embargo, el final de Fortuna es todavía más problemático de lo que acabamos de exponer, ya que el propio Júpiter, y todos sus colegas divinos, no se presentan, ni muchísimo menos, como moralmente superiores a los humanos. Tanto es así que la reunión de los dioses, que se supone que había de arreglar el mundo, termina, con una tragantona y una borrachera general, en un caos esperpéntico que excede con mucho el de los humanos que se escenifica al final del “cuadro»40, de forma que: «Tal cizaña derramó en todos [los dioses] el baile, que parecían azogados [...]. Dioles licencia [Júpiter] y hartos y contentos se afufaron, escurriendo la bola a puto el postre» (p. 809). El desprecio por parte del narrador hacia los compinches de la divinidad olímpica es, sin lugar a dudas, monumental.

57. La expresión que utiliza Quevedo en Mundo caduco (que comenzó a escribir en 1621) es: “Parecía con estas cosas estar en edad caduca el mundo furioso» (Quevedo, Mundo caduco, p. 92). En el «cuadro» 33 de Fortuna el embajador de Francia a Génova declara: «Hoy que parece está furioso el mundo» (p. 725). En el «cuadro» 39, Rabí Saadías, "viendo arder en discordias el mundo» (p. 774), habla de «estos delirios rabiosos en que parece está frenético todo el orbe de la tierra) (p. 777). Riandière la Roche (1979a, pp. $56,58)$ ve la raíz de todo ello en el pecado original, aunque en Fortuna no hay ningún indicio de que Quevedo piense así.

58. Quevedo, España defendida, p. 175. Quevedo especifica algunos de esos vicios: «Muchos en este tiempo entierra la gula. [...] Otros, del juego, que fue a moderados ánimos entretenimiento, hicieron oficio. [...] Las mujeres inventaron excesivo gasto a su adorno, y así la hacienda de la república sirve a su vanidad» (pp. 175-176). 
Refiriéndose a los dioses que prologan y epilogan los cuarenta «cuadros» de Fortuna, Lía Schwartz observa que son «representados como figuras grotescas que se expresan en lengua de germanía y vulgarismos $y$ van vestidos de jaques o tipos de mal vivir» ${ }^{59}$. Sin embargo, en realidad hay mucho más: los mismos dioses que supuestamente rigen el mundo son unos grandísimos sinvergüenzas que tienen la jeta de no oponerse a que la Fortuna siga siendo irracional e injusta con los pobres mortales, mientras ellos, los dioses, van sencillamente a la suya ${ }^{60}$. De hecho, esos dioses permiten tan sólo durante una hora que los quehaceres de la humanidad interrumpan las imbecilidades a que se dedican ellos en su carnavalesca vida olímpica. Dado que en Fortuna la divinidad se nos aparece como muchísimo más irrisible e irresponsable todavía que la humanidad, podría quedar la duda de si realmente cabe tomar en serio tanto sus opiniones como la decisión decretada finalmente por Júpiter.

No es fácil (es más bien imposible) averiguar hasta qué punto nuestro autor comparte las ideas 'progresistas' que él permite que se pronuncien en Fortuna. No obstante, lo que es incuestionable es la necesidad de reconocer que esas ideas se expresan allí, y de una manera harto contundente. Los indios y los negros ofrecen potentes argumentos contra el imperialismo, el belicismo y la discriminación racial, y no hay narrador ni protagonista que se les oponga. Y, en cuanto al discurso de la portavoz de las mujeres, aunque lo procure contestar el «triste doctor», cabe reconocer que su prédica es un fogoso llamamiento a una auténtica y justificada revolución feminista. En los episodios que hemos comentado, se trata de una serie de impresionantes parlamentos sobre la inaceptabilidad de lo que hoy en día llamaríamos colonialismo, racismo, esclavitud, discriminación de género e injusticia social ${ }^{61}$.

Ya nos hemos referido al hecho de que Luisa López Grigera opinase que los argumentos 'feministas' del «cuadro» 40 “increíbles pueden parecer en boca del escritor prototipo de la misoginia». Sin embargo, conviene precisar que esa opinión es errónea, ya que esos argumentos 'feministas' no aparecen en boca del escritor supuestamente prototipo de la misoginia. Aparecen -al igual que los argumentos a favor de los indios de Chile, de los negros y de una utopía-, en boca de uno (en este caso, una) de los protagonistas ficticios de esa compleja serie de discursos y debates que proliferan en la segunda parte de Fortuna. De manera que la cuestión es todavía más sutil y más «increíble», ya que lo que se revela es la voluntad por parte de ese autor pretendidamente tan reaccionario de dejar, por lo menos, que se ventilen ideas aparentemen-

59. Quevedo, La Hora de todos, 2009, pp. 29-30.

60. Iffland (1981, p. 77) pregunta acertadamente: «Chómo se puede tomar en serio la cordura de la decisión de Júpiter o la "providencia infalible" de los dioses cuando él y los demás se muestran como sibaritas amorales?».

61. Juárez (1995, p. 517) comenta: «Esta obra supera a las obras políticas anteriores, a las que les falta dialéctica, por su gran complejidad de estrategias retóricas que provocan numerosas interpretaciones». 
te tan contrarias a ( $\mathrm{o}$, por lo menos, tan diferentes de) las que se manifiestan en otras obras suyas. Lo cual quizás debiese hacernos preguntar hasta qué punto esa imagen de un Quevedo indisolublemente ultraconservador, defensor hasta la muerte de posiciones monárquicas, aristocráticas, patrióticas, sexistas y xenófobas depende, por lo menos en parte, del género literario que toca en cada momento. También podríamos preguntarnos hasta qué punto cabe tener en cuenta que muchas de sus obras políticas más beligerantes y polémicas sean memoriales que responden a crisis puntuales, nacionales e internacionales, como, entre otras, el comienzo del reinado de Felipe IV en 1621, la declaración de guerra por parte de Francia en 1635 o los intentos de secesión llevados a cabo por catalanes y portugueses a partir de 1640. Al mismo tiempo, ¿no convendría tener presente no tan sólo la inmensa variedad de géneros que ejerció, tanto en verso como en prosa, sino también el hecho de que fuese capaz de practicarlos simultáneamente, datando (por ejemplo) sus pragmáticas y memoriales burlescos, los primeros Sueños y el Buscón más o menos de la misma época de sus traducciones de Anacreonte y de Jeremías?

Finalmente, conviene también recordar que Fortuna se subtitula 'Fantasía moral', por lo cual podría entenderse que esta obra, que combina sátira y política, y que alterna pasajes altamente burlescos con otros profundamente serios, lo hace desde un punto de vista ético. En efecto, en Fortuna se dibuja un mundo que se podría mejorar radicalmente, pero se deja sin contestar la cuestión de si ese mundo mejor es, o no, pura fantasía ${ }^{62}$. Lo que nos ofrece la obra, entre otras tantas cosas más, es la visión de un Quevedo que no se parece en casi nada al monolítico reaccionario que se nos suele vender y que alguna que otra vez hayamos comprado y revendido. ¿Es poca cosa el que algunos de los temas que trata más seria y detenidamente en Fortuna sean tan impresionantemente actuales como la explotación de naciones colonizadas, la obscenidad de las guerras, la discriminación contra negros y mujeres, y la injusticia social? ${ }^{63}$ Más que de una burla de cualquier intento de reforma del mundo, a lo mejor convendría hablar de una apasionada

62. Iffland (1981, p. 42) afirma que el término 'Fantasía moral' connotaría cierta tensión entre los dos términos: por un lado, «la dimensión "apocalíptica", aquélla orientada hacia un vuelco profundo de la realidad en una "orgía" de pensamientos ilusorios»; por otro, "esa dimensión de la obra que mantiene todo dentro de "ciertos límites" (prescritos [...] por la formación ideológica dominante)».

63. Más de un crítico ha comentado la ambigüedad de Fortuna. Al igual que Bourg, Dupont y Geneste (Quevedo, L'heure de tous, 1980, p. 7), Iffland (1981, p. 29) se anticipaba al título del presente trabajo cuando llamaba Fortuna «una obra muy desconcertante, llena de las contradicciones y ambigüedades que residen en el corazón de Quevedo». El mismo crítico había mantenido que la obra "manifiesta un deseo (tanto al nivel consciente como en el inconsciente) de cambio radical en varias esferas (la política, la social, la económica, la ética)» (Iffland, 1981, p. 42). Bourg, Dupont y Geneste observan que la segunda parte de la obra «saca a la luz del día los falsos pretextos, las hipocresías, las mentiras de la política oficial de los Estados, invita a la reflexión y a la desconfianza» (Quevedo, La Hora de Todos, 1987, p. 48). 
desesperanza, una impotencia que se intenta paliar con una actitud estoicista y con el ansia de querer creer en una providencia divina ${ }^{64}$.

De todas formas, quizás el juicio más acertado (además de más autorizado) sobre la obra sea la genial definición de la misma que puso su propio autor en la dedicatoria de Fortuna que redactó en marzo de 1636 para Álvaro de Monsalve, canónigo de la catedral de Toledo: «El tratadiIlo, burla burlando, es de veras. Tiene cosas de las cosquillas, pues hace reír con enfado y desesperación» (p. 810). Ya lo dijo Américo Castro, hace casi noventa años: "Quevedo es un campo de contradicciones». ${ }^{65}$ Sin duda, es un genio más complejo y más desconcertante de lo que muchas veces solemos reconocer, capaz, en efecto, de hacer reír con enfado y desesperación.

\section{Bibliografía}

Baum, Doris L., Traditionalism in the Works of Francisco de Quevedo y Villegas, Chapel Hill, University of North Carolina Press, 1970.

Caminero, Juventino, Víctima o verdugo. Conservadurismo y antisemitismo en el pensamiento político-social de Quevedo, Kassel, Universidad de Deusto / Reichenberger, 1984.

Candelas Colodrón, Manuel Ángel, «Los exempla femeninos en la obra grave de Quevedo», La Perinola, 9, 2005, pp. 32-54.

Castro, Américo, "Escepticismo y contradicción en Quevedo», Humanidades (Universidad Nacional de la Plata), 18, 1928, 11-17.

Clamurro, William H., "La Hora de todos y la geografía política de Quevedo», en Actas del $x$ Congreso de la Asociación Internacional de Hispanistas, Barcelona 21-26 de agosto de 1989, ed. Antonio Vilanova, Barcelona, PPU, 1992, pp. 841-847. http://cvc.cervantes.es/literatura/aih/pdf/10/aih_10_1_090.pdf

Clamurro, William H., «The Victim's Voice: Empire and Marginality in La Hora de todosm, en Studies in Honor of James O. Crosby, ed. Lía Schwartz, Newark, Juan de la Cuesta, 2004, pp. 91-108.

Czeglédi, Aurora, «La anamorfosis semántica en el segundo debate del cuadro XL de La Hora de todos y la Fortuna con sesom, La Perinola, 14, 2010, pp. 6982.

Ettinghausen, Henry, «Quevedo, ¿un caso de doble personalidad?», en Homenaje a Quevedo, ed. Víctor García de la Concha, Salamanca, Ediciones Universidad de Salamanca, 1982, pp. 27-44.

Ettinghausen, Henry, «Austeridad varonil vs. consumismo afeminado: Quevedo ante el final del reinado de Felipe II», La Perinola, 3, 1999, pp. 143-155.

Ettinghausen, Henry, «La sátira antijudía de Quevedo», en Estudios sobre la sátira española en el Siglo de Oro, ed. Carlos Vaíllo y Ramón Valdés, Madrid, Castalia, 2006, pp. 59-79.

64. José Martínez Millán (2014, p. 104, nota 3) nombra únicamente, y sin motivo alguno, un artículo mío (Ettinghausen, 1982) para justificar su aserto de que algunos estudiosos consideran que Quevedo fue «un personaje poco sincero y adaptado». De dicho artículo es evidente que no ha leído más que el título.

65. Castro, 1928, p. 16. Refiriéndose al Quevedo de Fortuna, Price (1975, p. 113) habla de «his use of partial truth, doubtful testimony and the untruth of his own fiction in certain sections as a means of satire». 
Ettinghausen, Henry, Quevedo neoestoico, Pamplona, Eunsa, 2009.

Fernández Mosquera, Santiago, «Ideología y literatura: perturbaciones literarias en la exégesis ideológica de la obra de Quevedom, La Perinola, 1, 1997, pp. 151-169.

Gow, Andrew Colin, The Red Jews: Antisemitism in an Apocalyptic Age, 12001600, Leiden, Brill, 1994.

Iffland, James, «Apocalypse Later: Ideology and Quevedo's La Hora de todos», Revista de Estudios Hispánicos (Puerto Rico) 7, 1980, pp. 87-132.

Iffland, James, “Apocalipsis más tarde: Ideología y La Hora de todos», en Cotextes, Francisco de Quevedo, La hora de todos, Montpellier, CERs, 1981, pp. 27-97.

Juárez, Encarnación, “La Hora de todos: ¿ambigüedad calculada o cambio de actitud de Quevedo?», Revista Canadiense de Estudios Hispánicos, 19, 1995, pp. 505-521.

López Grigera, Luisa, "Relección de La Hora de todos de Quevedo», Lección inaugural del curso académico 1971-1972, Universidad de Deusto, Deusto / Bilbao, 1971.

Kent, Conrad, “Politics in La Hora de todos», Journal of Hispanic Philology, 1, 1977, pp. 99-119.

Martínez Millán, José, «Reflexiones en torno a los escritos políticos e históricos de Francisco de Quevedom, La Perinola, 18, 2014, pp. 103-141.

Molho, Maurice, “Una cosmogonía antisemita: "Érase un hombre a una nariz pegado"», en Quevedo in Perspective, ed. James Iffland, Newark, Juan de la Cuesta, 1982, pp. 57-80.

Nider, Valentina, «Política y retórica en La Hora de todos: las orationes fictae (con una mirada hacia Marco Bruto)», Studia Aurea Monográfica, 1, 2010, pp. 319334.

Price, R. M., «Fiction and False Testimony in La Hora de todos», Romanic Review, 66, 1975, pp. 113-122.

Quevedo, Francisco de, Discurso de todos los diablos, ed. Alfonso Rey, en Obras completas en prosa, dir. Alfonso Rey, vol. 1, tomo 2, Madrid, Castalia, 2003, pp. 469-560.

Quevedo, Francisco de, El chitón de las tarabillas, ed. Manuel Ángel Candelas Colodrón, en Obras completas en prosa, dir. Alfonso Rey, vol. 3, Madrid, Castalia, 2005, pp. 185-247.

Quevedo, Francisco de, España defendida de los tiempos de ahora de las calumnias de los noveleros y sediciosos, ed. Victoriano Roncero López, Pamplona, Eunsa, 2013.

Quevedo Villegas, Francisco de, Execración contra los judíos, ed. Fernando Cabo Aseguinolaza y Santiago Fernández Mosquera, Barcelona, Crítica, 1993.

Quevedo Villegas, Francisco de, La Hora de todos y la Fortuna con seso, en Obras, ed. Aureliano Fernández-Guerra y Orbe, Madrid, Atlas, 1946, vol. 1, pp. 381-425, BAE, 23.

Quevedo, Francisco de, La Hora de todos, ed. Luisa López Grigera, Madrid, Castalia, 1975.

Quevedo, Francisco de, L'heure de tous et la fortune raisonnable / La Hora de todos y la fortuna con seso, ed. y trad. Jean Bourg, Pierre Dupont y Pierre Geneste, Paris, Aubier-Montaigne, 1980.

Quevedo, Francisco de, La Hora de todos y la Fortuna con seso, ed. Jean Bourg, Pierre Dupont y Pierre Geneste, Madrid, Cátedra, 1987. 
Quevedo, Francisco de, La Fortuna con seso y la Hora de todos. Fantasía moral, ed. Lía Schwartz, en Obras completas en prosa, dir. Alfonso Rey, Madrid, Castalia, 2003, vol. 1, tomo 2, pp. 561-892.

Quevedo, Francisco de, La Hora de todos y la Fortuna con seso, ed. Lía Schwartz, Madrid, Castalia, 2009.

Quevedo, Francisco de, Mundo caduco, ed. Javier Biurrun Lizarazu, Pamplona, Eunsa, 2000.

Quevedo, Francisco de, Poesía original completa, ed. José Manuel Blecua, Barcelona, Planeta, 1981.

Quevedo, Francisco de, Providencia de Dios (Tratado de la inmortalidad del alma y Tratado de la divina providencia), ed. Sagrario López Poza, Janus [en línea], Anexo 4 (2015), publicado el 23/12/2015, consultado el 02/03/2016. URL: 〈http://www.janusdigital.es/anexo.htm?id=8>

Quevedo, Francisco de, Sueños y discursos, ed. Ignacio Arellano, en Obras completas en prosa, dir. Alfonso Rey, Madrid, Castalia, 2003, vol. 1, tomo 1, pp. 185-467.

Ramírez, Alejandro, Epistolario de Justo Lipsio y los españoles (1577-1606), Madrid, Castalia, 1966.

Rey, Alfonso, “La construcción crítica de un Quevedo reaccionario», Bulletin hispanique, 112, 2010, pp. 633-669.

Riandière la Roche, Josette, «La satire du monde à l'envers et ses implications politiques dans La Hora de todos de Quevedo", en L'image du monde renversé et ses représentations littéraires et para-littéraires de la fin du XVI siècle au milieu du XVII, ed. Jean Lafond y Augustin Redondo, Paris, Vrin, 1979a, pp. 55-71.

Riandière la Roche, Josette, «Nota para una mejor comprensión de un texto de Quevedo: La Hora de todos,, en Hommage des Hispanistes français à Noël Salomon, Barcelona, Laia, 1979b, pp. 725-732.

Riandière la Roche, Josette, “Quevedo et le problème de l'esclavage des Noirs dans La Hora de todosm, en La contestation de la société dans la littérature espagnole du Siècle d'Or, Travaux de l'Université de Toulouse-le-Mirail, Université de Toulouse-le-Mirail, Service des Publications, 1981, vol. 17, pp. 165-178.

Riandière la Roche, Josette, «Quevedo et les indiens du Nouveau Monde. Entre littérature et histoire», en Vingt études sur le Mexique et le Guatemala réunies à la mémoire de Nicole Percheron, ed. Alain Breton, Jean-Pierre Berthe y Sylvie Lecoin, Toulouse, Presses Universitaires du Mirail, 1991, pp. 13-32.

Roncero López, Victoriano, "Chile en Quevedo: el cuadro xxxvi de La Hora de todos y la fortuna con sesom, Anales de Literatura Chilena, 13, 2010, pp. 13-36.

Schwartz Lerner, Lía, «La mujer toma la palabra: voces femeninas en la sátira del siglo XVII", en Images de la femme en Espagne au XVI et XVII siècles. Des traditions aux renouvellements et à l'émergence d'images nouvelles, ed. Augustin Redondo, Paris, Publications de la Sorbonne Nouvelle, 1994, pp. 381-390. 